Article

\title{
Antioxidant Properties of Water-Soluble Gum from Flaxseed Hulls
}

\author{
Fatma Bouaziz ${ }^{1, \dagger}$, Mohamed Koubaa ${ }^{2, \dagger}$, Francisco J. Barba ${ }^{3, *}$, Shahin Roohinejad ${ }^{4}$ \\ and Semia Ellouz Chaabouni 1,5 \\ 1 Enzyme Bioconversion Unit (UR13ES74), National School of Engineering, Sfax University, Sfax 3030, Tunisia; \\ fatma.bouaziz22@yahoo.fr (F.B.); semia.chaabouni@enis.rnu.tn (S.E.C.) \\ 2 Département de Génie des Procédés Industriels, Laboratoire Transformations Intégrées de la Matière \\ Renouvelable (UTC/ESCOM, EA 4297 TIMR), Université de Technologie de Compiègne, \\ Compiègne Cedex 60203, France; m.koubaa@escom.fr \\ 3 Faculty of Pharmacy, Universitat de València, Avda, Vicent Andrés Estellés, s/n 46100 Burjassot, \\ València 46940, Spain \\ 4 Burn and Wound Healing Research Center, Division of Food and Nutrition, \\ Shiraz University of Medical Sciences, Shiraz 7198754361, Iran; falcon.roh@gmail.com \\ 5 Common Service Unit of Bioreactor Coupled with an Ultrafilter, National School of Engineering, \\ Sfax University, Sfax 3030, Tunisia \\ * Correspondence: francisco.barba@uv.es; Tel.: +34-963-544-972 \\ + Fatma Bouaziz and Mohamed Koubaa participated equally to this work.
}

Academic Editors: Farid Chemat and Maryline Abert-Vian

Received: 21 June 2016; Accepted: 27 July 2016; Published: 2 August 2016

\begin{abstract}
Soluble flaxseed gum (SFG) was extracted from flax (Linum usitatissimum) hulls using hot water, and its functional groups and antioxidant properties were investigated using infrared spectroscopy and different antioxidant assays (2,2-diphenyl-1-picrylhydrazyl (DPPH), 2,2'-azino-bis(3-ethylbenz othiazoline-6-sulphonic acid (ABTS), reducing power capacity, and $\beta$-carotene bleaching inhibition assay), respectively. The antioxidant capacity of SFG showed interesting DPPH radical-scavenging capacity $\left(\mathrm{IC}_{50} \mathrm{SFG}=2.5 \mathrm{mg} \cdot \mathrm{mL}^{-1}\right)$, strong ABTS radical scavenging activity (\% inhibition $\mathrm{ABTS}=75.6 \% \pm 2.6 \%$ at $\left.40 \mathrm{mg} \cdot \mathrm{mL}^{-1}\right)$, high reducing power capacity $\left(\mathrm{RP}_{\mathrm{SFG}}=5 \mathrm{mg} \cdot \mathrm{mL}^{-1}\right)$, and potent $\beta$-carotene bleaching inhibition activity $\left(\mathrm{IC}_{50} \mathrm{SFG}=10 \mathrm{mg} \cdot \mathrm{mL}^{-1}\right)$. All of the obtained results demonstrate the promising potential use of SFG in numerous industrial applications, and a way to valorize flaxseed hulls.
\end{abstract}

Keywords: flax hull; flaxseed gum; antioxidant properties

\section{Introduction}

Flax (Linum usitatissimum L.) was first cultivated as a fiber crop; nonetheless, its value and importance as an oil source has been interestingly increased [1]. From a health point of view, agri-food and pharmaceutical industries have shown a growing interest in flax seeds due to their richness in nutritionally valuable compounds, such as lignans (i.e., secoisolariciresinol diglucoside, $\alpha$-linolenic acid, and soluble flaxseed gum (SFG) [2,3]. SFG, called also mucilage, is mainly present in the outermost layer of the seed hull [4], and can be released by soaking in water [5]. Previous works showed that a better extraction of SFG could be performed during $3 \mathrm{~h}$ at a temperature ranging from 85 to $95^{\circ} \mathrm{C}$, and a $\mathrm{pH}$ ranging from 6.5 to 7.0 [6]. The monosaccharide composition of SFG showed the presence of fucose, rhamnose, arabinose, galactose, glucose, and xylose, with the respective percentages of $7.0 \pm 0.2,16.5 \pm 0.6,12.7 \pm 0.1,22.4 \pm 1.0,2.7 \pm 0.1$, and $38.6 \pm 1.2$ [5]. SFG exhibits interesting features that allow it to be used in numerous industrial applications. For instance, its low viscosity (shear rate ranging from 10 to $1000 \mathrm{~s}^{-1}$ ) compared to other gums, such as locust 
bean gum, guar gum, and xanthan gum [7] gives it the promising fortification properties of fibers in food products [5]. Despite the numerous studies describing the health-related benefits of flax seeds and their food applications [8-12], little interest has been reported on the role of SFG in promoting human health [13,14]. Fractionating flax seed to kernel and hull-representing $63 \%$ and $37 \%$ of the total seed weight [15], respectively-is of great importance, as it allows an oil-rich fraction (kernel) and a gum-rich fraction (hull) to be obtained, thus reducing the downstream processing cost and increasing the profitability. Numerous studies have shown interest in valorizing flaxseed hulls by extracting the residual oil [16], proteins and polyphenols [17,18], as well as SFG, with some potential applications [19-24]. Investigating other health-related benefits of SFG-such as its antioxidant potential, which has not been described before-is interesting, as it may lead to the replacement of some synthetic antioxidants, which are more and more restricted by legislation [25]. In fact, water-soluble polysaccharides extracted from plant materials and by-products may exhibit antioxidant activities, such as those extracted from red prickly pear peels [26], almond gum [27], garlic straw [28], almond and pistachio juice processing by-products [29], and many other examples. In this line, this work aims at extracting SFG from hulls and evaluating its antioxidant properties.

\section{Materials and Methods}

\subsection{Chemicals}

ABTS (2,2'-azino-bis(3-ethylbenzothiazoline-6-sulphonic acid), DPPH (2,2-diphenyl-1- picrylhydrazyl), BHA (butylated hydroxyanisole), Trolox (6-hydroxy-2,5,7,8-tetramethylchroman- 2-carboxylic acid), sodium tetraborate, sodium phosphate, ferric chloride, petroleum ether, and trichloroacetic acid were purchased from Sigma-Aldrich (Darmstadt, Germany). Ethanol and sulfuric acid were purchased from Scharlab (Barcelona, Spain). Ammonium molybdate was obtained from NenTech Ltd. (London, UK), and potassium ferricyanide was obtained from Loba Chemie (Mumbai, India). Commercial gum arabic, purchased from a local market (Sfax, Tunisia), was the hydrocolloid used as reference.

\subsection{Plant Material}

Flaxseed (Linum usitatissimum) hulls (Figure 1) of the "Comtess" variety were obtained after mechanical dehulling of seeds by abrasion.

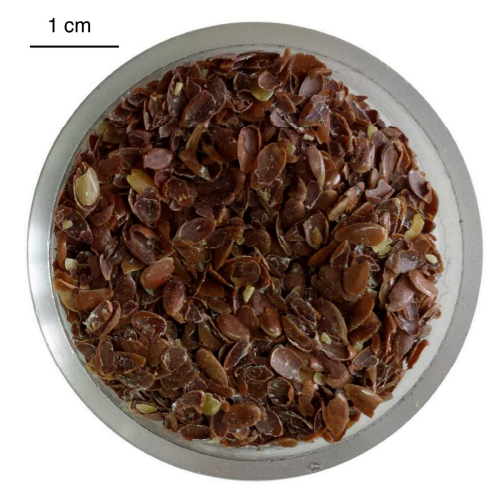

Figure 1. Physical aspect of flaxseed hulls.

\subsection{Characterization of Flaxseed Hulls}

Lipid content was determined by Soxhlet method, as previously reported [30], with slight modification. In brief, $2 \mathrm{~g}$ of ground hulls were extracted under reflux with $250 \mathrm{~mL}$ petroleum ether for $6 \mathrm{~h}$. The solvent was evaporated using a rotary evaporation system at $50^{\circ} \mathrm{C}$, and oil content was determined by measuring the weight difference before and after extraction. 
Dry matter was determined by drying the hulls at $105^{\circ} \mathrm{C}$ in an oven until reaching constant weight, according to the "Association Française de Normalisation" (AFNOR) [31]. Total nitrogen content was determined according to Kjeldahl's method [32], and protein content was determined by multiplying the nitrogen content by 6.25 [5]. Total sugar content was determined as previously described [33]. Total ash was determined after combustion of $5 \mathrm{~g}$ hulls for $4 \mathrm{~h}$ in a muffle furnace maintained at $550^{\circ} \mathrm{C}$. The mineral composition $(\mathrm{K}, \mathrm{Ca}, \mathrm{Mg}$, and $\mathrm{Mn}$ ) of ash was determined by flame atomic absorption spectrometry (Analytic Jena ZEEnit 700 spectrometer, Analytik Jena, Germany) [34].

\subsection{Soluble Flaxseed Gum Extraction}

Soluble flaxseed gum (SFG) were extracted from hulls as previously described [26]. In brief, $20 \mathrm{~g}$ of hulls was mixed with $500 \mathrm{~mL}$ distilled water in a $1 \mathrm{~L}$ rounded bottom flask. The hulls/water mixture was then brought to a boil for $4 \mathrm{~h}$, using heating mantle under reflux. Afterwards, the mixture was recovered and filtered through paper filter under vacuum. The extraction was repeated three times using the same plant material, in order to recover the maximum amount of polysaccharides. The supernatants were pooled and concentrated 20 times using a vacuum rotary evaporation system, maintained at $50^{\circ} \mathrm{C}$. Twenty milliliters of concentrated SFG solution was obtained after this evaporation step. SFG was precipitated overnight by adding $100 \mathrm{~mL}$ ethanol $96 \%$ (final ethanol concentration $=80 \%$ ) at $-20^{\circ} \mathrm{C}$, and then recovered by $15 \mathrm{~min}$ centrifugation at $5000 \mathrm{~g}$. The recovered SFG was subjected to five washing steps in order to remove the small molecules. The procedure consists of resuspending the SFG in $20 \mathrm{~mL}$ water, precipitation by adding $20 \mathrm{~mL}$ of ethanol $96 \%$, and centrifugation as described above. Minerals were removed by dialysis (molecular cutoff $=500 \mathrm{Da}$ ) using bidistilled water for 3 days. The obtained desalted samples were freeze-dried and stored at $4{ }^{\circ} \mathrm{C}$ until analysis.

\subsection{Fourier Transform Infrared Spectroscopic Analysis}

SFG functional group analysis was assessed by Fourier transform infrared (FTIR) spectroscopy using Analect Instrument fx-6160 (Irvine, CA, USA) as previously described [29]. The transmission (\%) was recorded between 650 and $4000 \mathrm{~cm}^{-1}$ after mixing $1 \mathrm{mg}$ from the lyophilized SFG sample with $100 \mathrm{mg} \mathrm{KBr}$. The SFG spectrum was then compared to the FTIR spectrum of gum arabic, in order to check for similarities.

\subsection{Antioxidant Activities of Soluble Flaxseed Gum (SFG)}

\subsubsection{DPPH Free Radical Scavenging Activity}

The ability of SFG to scavenge DPPH free radicals was evaluated as previously described [26]. In brief, different amounts (1-20 mg) of SFG were resuspended in $0.5 \mathrm{~mL}$ distilled water, and then mixed with $0.375 \mathrm{~mL}$ absolute ethanol and $125 \mu \mathrm{L}$ DPPH solution ( $0.02 \%$ in ethanol). The mixtures were then vortexed and kept in the dark for $60 \mathrm{~min}$ at room temperature. DPPH, initially having deep violet color in solution, becomes colorless or pale yellow in the presence of SFG. Color changes were followed spectrophotometrically (Shimadzu UV/VIS mini 1240, Fisher Scientific, Illkirch, France) at $517 \mathrm{~nm}$, and the absorbance was recorded as $\mathrm{A}_{\text {sample. }}$. A control solution without SFG was prepared under the same conditions by mixing $125 \mu \mathrm{L}$ DPPH solution with $875 \mu \mathrm{L}$ absolute ethanol, and the absorbance was recorded as $A_{\text {control }}$. A blank solution without DPPH was prepared by mixing SFG (1-20 mg) with $0.5 \mathrm{~mL}$ distilled water and $0.5 \mathrm{~mL}$ absolute ethanol, and the absorbance was recorded as $\mathrm{A}_{\text {blank }}$. The free radical scavenging activity (\% inhibition) was calculated according to Equation (1).

$$
\text { Inhibition } \%=\frac{\mathrm{A}_{\text {control }}+\mathrm{A}_{\text {blank }}-\mathrm{A}_{\text {sample }}}{\mathrm{A}_{\text {control }}} \times 100
$$




\subsubsection{ABTS Free Radical Scavenging Activity}

The antiradical activity of SFG was also determined against the free radical 2,2'-azino-bis (3-ethylbenzothiazoline-6-sulphonic acid) (ABTS) based on the discoloration of cations, as previously described [35]. A solution of ABTS $(7 \mu \mathrm{M})$ was prepared in distilled water and was mixed with a solution of potassium persulfate $(2.45 \mu \mathrm{M})$. Prior to use, the mixture was kept in the dark for $16 \mathrm{~h}$ at room temperature. The resulting intense color matches the $\mathrm{ABTS}^{\bullet+}$ radical cations, and the obtained solution was subsequently diluted with distilled water until an absorbance of $0.7 \pm 0.02$, measured at $734 \mathrm{~nm}$. One milliliter of ABTS ${ }^{\bullet+}$ diluted solution $\left(\mathrm{A}_{734 \mathrm{~nm}}=0.7 \pm 0.02\right)$ was mixed with $10 \mu \mathrm{L}$ of SFG solution at different concentrations ( 5 to $40 \mathrm{mg} \cdot \mathrm{mL}^{-1}$ ), and the reaction mixture was kept at room temperature for $6 \mathrm{~min}$ before measuring the absorbance at $734 \mathrm{~nm}$. The assay relies on the ability of the antioxidant molecules to inhibit the oxidation of ABTS radical cation in ABTS ${ }^{\bullet+}$. SFG scavenging activity (calculated as \% of inhibition) was determined according to Equation (2).

$$
\text { Inhibition } \%=\left(1-\frac{\mathrm{A}}{\mathrm{A}_{0}}\right) \times 100
$$

where $\mathrm{A}$ and $\mathrm{A}_{0}$ represent respectively the absorbance values of the solutions containing or not containing the free radical $\mathrm{ABTS}^{\bullet+}$.

\subsubsection{Total Antioxidant Activity}

The total antioxidant activity of SFG was evaluated as previously described [25], with slight modifications. In brief, the experiment consisted of mixing different amounts $(5,7.5,10$, and $15 \mathrm{mg})$ of SFG with $1 \mathrm{~mL}$ of freshly prepared reagent solution $(28 \mathrm{mM}$ sodium phosphate, $4 \mathrm{mM}$ ammonium molybdate, and $0.6 \mathrm{M}$ sulfuric acid). The volume in each tube was made up to $1.1 \mathrm{~mL}$ with distilled water, and all tubes were kept for $90 \mathrm{~min}$ at $90{ }^{\circ} \mathrm{C}$ in a thermostatic water bath. Total antioxidant activity was measured at $695 \mathrm{~nm}$ after cooling to room temperature and was expressed as ascorbic acid equivalent using a previously established standard curve. A blank solution was prepared by mixing $1 \mathrm{~mL}$ reagent with $100 \mu \mathrm{L}$ distilled water, under the same conditions of the samples.

\subsubsection{Reducing Power Capacity}

Reducing power capacity of SFG was measured as previously described [36], with slight modifications. Different amounts of SFG (1-20 mg) were mixed with $0.5 \mathrm{~mL}$ distilled water, $1.25 \mathrm{~mL}$ phosphate buffer $(0.2 \mathrm{M}, \mathrm{pH} 6.6)$, and $1.25 \mathrm{~mL}$ potassium ferricyanide ( $1 \%(w / v)$ prepared in water). The mixtures were kept for $20 \mathrm{~min}$ at $50{ }^{\circ} \mathrm{C}$ in a thermostatic water bath. One milliliter trichloroacetic acid $(10 \%(w / v)$ prepared in water) was added to the reaction mixture after cooling to room temperature. All tubes were then centrifuged for $10 \mathrm{~min}$ at $3000 \mathrm{~g}$. From each supernatant, $1.5 \mathrm{~mL}$ was taken and mixed with $1.5 \mathrm{~mL}$ distilled water and $100 \mu \mathrm{L}$ freshly prepared ferric trichloride solution $(0.1 \%(w / v)$ prepared in water). After vortexing, the absorbance was measured at $700 \mathrm{~nm}$. A blank solution (without SFG) was prepared under the same conditions.

\subsection{5. $\beta$-carotene Bleaching Test}

The test evaluating $\beta$-carotene bleaching by SFG was performed as previously described [25], with slight modifications. A fresh mixture solution was prepared by dissolving $0.5 \mathrm{mg} \beta$-carotene, $25 \mu \mathrm{L}$ linoleic acid, and $200 \mu \mathrm{L}$ Tween 40 in $1 \mathrm{~mL}$ chloroform. The solvent used was then evaporated under vacuum at $40{ }^{\circ} \mathrm{C}$, and $100 \mathrm{~mL}$ bi-distilled water was added to dissolve the different constituents. Different amounts of SFG (1-20 mg) were mixed with $2.5 \mathrm{~mL}$ of the prepared emulsion, and all tubes 
were kept for $2 \mathrm{~h}$ in an oven maintained at $50{ }^{\circ} \mathrm{C}$. $\beta$-carotene bleaching was evaluated by measuring the absorbance at $470 \mathrm{~nm}$ before and after incubation $\left(\mathrm{A}_{0 \mathrm{~h}}\right.$ and $\mathrm{A}_{2 \mathrm{~h}}$, respectively), using Equation (3).

$$
\text { Inhibition } \%=\left(1-\frac{\mathrm{A}_{0 \mathrm{~h}(\mathrm{WSP})}-\mathrm{A}_{0 \mathrm{~h}(\text { control })}}{\mathrm{A}_{2 \mathrm{~h}(\mathrm{WSP})}-\mathrm{A}_{2 \mathrm{~h}(\text { control })}}\right) \times 100
$$

where $\mathrm{A}_{0 \mathrm{~h} \text { (control) }}$ and $\mathrm{A}_{2 \mathrm{~h} \text { (control) }}$ represent the absorbance values of a control solution $(0.5 \mathrm{~mL}$ bi-distilled water instead of SFG solution) before and after incubation, respectively.

\subsubsection{Statistical Analysis}

Antioxidant activities were performed in triplicate, and results were expressed as average values with standard deviation (SD). Multiple sample comparison of the means was done using analysis of variance (ANOVA) (using software SPSS Version 22; IBM ${ }^{\circledR}$ SPSS ${ }^{\circledR}$ Statistics, USA) and was used to determine the significant differences between the results, with a significance level of $p<0.05$.

\section{Results and Discussion}

\subsection{Flaxseed Hull Characterization}

Table 1 shows the physico-chemical composition of SFG from hulls. Dry matter $(7.5 \pm 0.7 \%)$ was similar to that reported for whole flaxseed, which is in the range of $7 \%-9 \%$, depending on the variety [37]. Protein content was similar $(18.36 \% \pm 0.12 \%)$ to whole flaxseed $(\approx 18 \%)$ [38], and was slightly higher than that reported for rapeseed hulls (15.27\%) [30]. Lipid content was very low $(6.53 \% \pm 0.23 \%$, dry basis $)$ compared to that accumulated by whole flaxseed $(\approx 42 \%)$ [38]. This content depends on the variety, the moisture content, and the dehulling procedure. It should be noted that oil content in flaxseed hulls was lower than that reported for rapeseed hulls $(21.7 \% \pm 1.8 \%$, dry basis), probably due to the easier way to dehull flaxseeds compared to rapeseeds. Total sugars, by contrast to oil content, was relatively high $(65.41 \% \pm 1,2 \%$, dry basis), and was higher than that reported for whole flaxseed (28.9\%, dry basis) [38]. Total ash $(1.99 \% \pm 0.01 \%$, dry basis) was mainly composed of potassium (115.15 $\pm 0.75 \mathrm{mg} / 100 \mathrm{~g}$ hulls), calcium (115.25 $\pm 1.35 \mathrm{mg} / 100 \mathrm{~g}$ hulls), and magnesium (52.69 $\pm 0.53 \mathrm{mg} / 100 \mathrm{~g}$ hulls), with the minor presence of zinc $(0.86 \pm 0.02 \mathrm{mg} / 100 \mathrm{~g}$ hulls $)$ and manganese (0.48 $\pm 0.02 \mathrm{mg} / 100 \mathrm{~g}$ hulls).

Table 1. Physico-chemical composition of flaxseed hulls.

\begin{tabular}{ccc}
\hline Compound & Dry Basis \% & Dry Matter $\mathbf{~ g} / \mathbf{1 0 0} \mathbf{g}$ \\
\hline Dry matter & $7.5 \pm 0.7$ & \\
Proteins & $18.36 \pm 0.12$ & \\
Lipids & $6.53 \pm 0.23$ & \\
Sugars & $65.41 \pm 1,2$ & \\
Ash & $1.99 \pm 0.01$ & \\
$\mathrm{~K}^{+}$ & & $115.15 \pm 0.75$ \\
$\mathrm{Ca}^{2+}$ & & $115.25 \pm 1.35$ \\
$\mathrm{Mg}^{2+}$ & & $52.69 \pm 0.53$ \\
$\mathrm{Zn}^{2+}$ & & $0.86 \pm 0.02$ \\
$\mathrm{Mn}^{2+}$ & & $0.48 \pm 0.02$ \\
\hline
\end{tabular}

\subsection{FTIR Characterization}

After lyophilization, SFG presented $12.5 \% \pm 1.19 \%$ dry basis, which could represent a considerable amount of polysacchrides to be valorized as food additives. The extracted SFG were characterized by FTIR (650-4000 $\mathrm{cm}^{-1}$ ) and compared to the spectrum of gum arabic (Figure 2). Three characteristic transitions of polysaccharides were observed in the different samples; at 3000-3700 $\mathrm{cm}^{-1}, 1500-1770 \mathrm{~cm}^{-1}$, and 950-1200 $\mathrm{cm}^{-1}$. Similar results have been reported previously [39-41]. Stretching of the hydroxyl 
groups was confirmed by the presence of the peak at $\approx 3400 \mathrm{~cm}^{-1}$, whereas $\mathrm{C}-\mathrm{H}$ stretching and bending vibrations are confirmed by the presence of the peak observed at $2922 \mathrm{~cm}^{-1}$ [41]. Moreover, the stretching vibrations of $\mathrm{C}-\mathrm{O}$ bonds are represented by the peak observed at $1634 \mathrm{~cm}^{-1}$. It has been previously reported that the presence of pyranose units in the structure is associated with the presence of the bands at $1073 \mathrm{~cm}^{-1}$ and $1039 \mathrm{~cm}^{-1}$ [41-43]. The obtained results demonstrated similar functional groups between SFG and gum arabic, which indicates that SFG probably has a polysaccharidic structure. FTIR data thus provide a preliminary overview on the presence of polysaccharides in the extract. Similar spectra were previously reported for polysaccharides extracted from red prickly pear peels [26], almond, and pistachio juice processing by-products [29], and for almond gum and gum arabic [44,45].

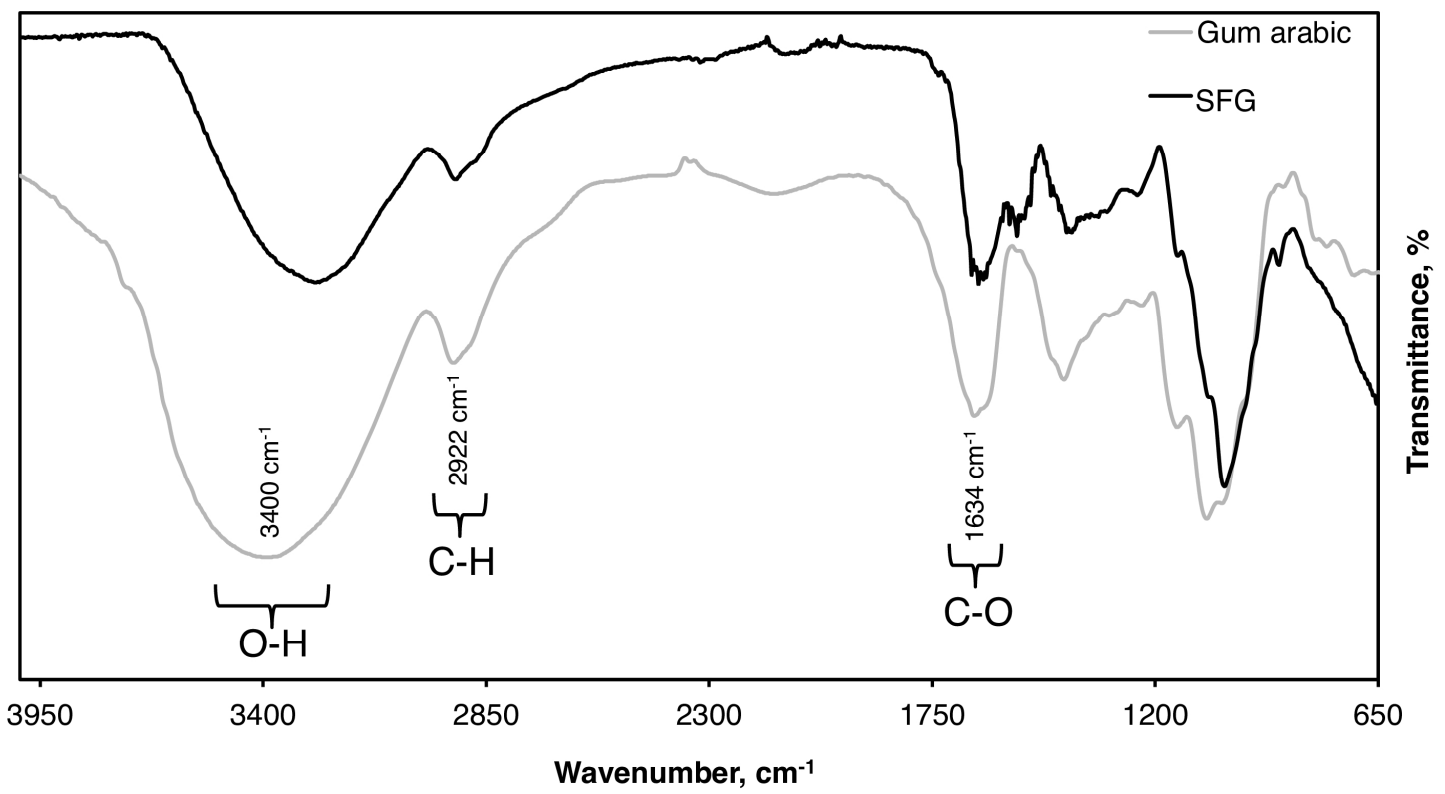

Figure 2. FTIR spectra of soluble flaxseed gum (SFG) and gum arabic. Spectra were recorded between $650 \mathrm{~cm}^{-1}$ and $4000 \mathrm{~cm}^{-1}$ wavenumber. The most prominent peaks correspond to $\mathrm{O}-\mathrm{H}, \mathrm{C}-\mathrm{H}$, and $\mathrm{C}-\mathrm{O}$ stretching vibrations.

\subsection{Antioxidant Activity of SFG}

Antioxidant molecules are able to reduce the stable radical DPPH, having a deep violet color in solution, to the yellow-colored 1,1-diphenyl-2-picrylhydrazyl. The free radical scavenging activity of SFG was assessed by DPPH test (Figure 3a). The obtained results showed that the percentage of inhibition was proportional to the concentration of SFG used. The highest DPPH free radical scavenging activity $(\approx 100 \%)$ was observed beyond $\approx 10 \mathrm{mg} \cdot \mathrm{mL}^{-1}$. The half inhibition concentration $\left(\mathrm{IC}_{50}\right)$ value of SFG was also determined, corresponding to $2.5 \mathrm{mg} \cdot \mathrm{mL}^{-1}$. The lowest $\mathrm{IC}_{50}$ value corresponds to the highest DPPH scavenging activity. Results demonstrated that the $\mathrm{IC}_{50}$ value of SFG was lower than that reported for other polysaccharides, such as those extracted from guara fruits $\left(\mathrm{IC}_{50}=10.8 \mathrm{mg} \cdot \mathrm{mL}^{-1}\right)$ [43], red prickly pear peels $\left(\mathrm{IC}_{50}=10.8 \mathrm{mg} \cdot \mathrm{mL}^{-1}\right)$ [26], and almond juice processing by-products $\left(\mathrm{IC}_{50}=2.87 \mathrm{mg} \cdot \mathrm{mL}^{-1}\right)$ [29], and was higher than that found for polysaccharides extracted from garlic straw $\left(\mathrm{IC}_{50}=740 \mu \mathrm{g} \cdot \mathrm{mL}^{-1}\right)$ [28] and pistachio juice processing by-products $\left(\mathrm{IC}_{50}=1.61 \mathrm{mg} \cdot \mathrm{mL}^{-1}\right)$ [29]. Compared to BHA, SFG showed good scavenging activity, which demonstrates its ability to react with free radicals and reduce them to more stable products.

Similarly to DPPH free radical, ABTS showed potential scavenging activity and again demonstrated its ability to reduce free radicals and convert them to more stable products. Results are presented in Figure $3 \mathrm{~b}$ and show that the scavenging activity is proportional to the concentration of SFG. The highest percentage of inhibition $(75.6 \% \pm 2.6 \%)$ was observed at $40 \mathrm{mg} \cdot \mathrm{mL}^{-1}$, which was lower 
than that observed for DPPH at the same concentration. The $\mathrm{IC}_{50}$ value of SFG was also determined, corresponding to $26.1 \mathrm{mg} \cdot \mathrm{mL}^{-1}$. However, ABTS scavenging activity remains lower than that observed for Trolox, used as standard.

(a)

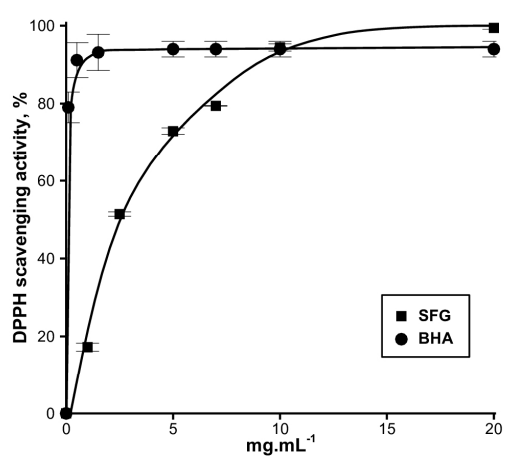

(c)

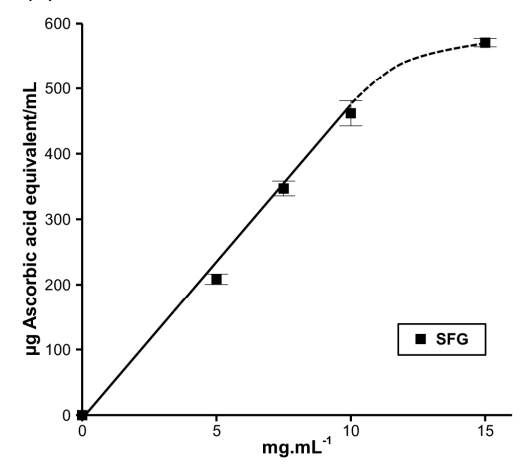

(b)

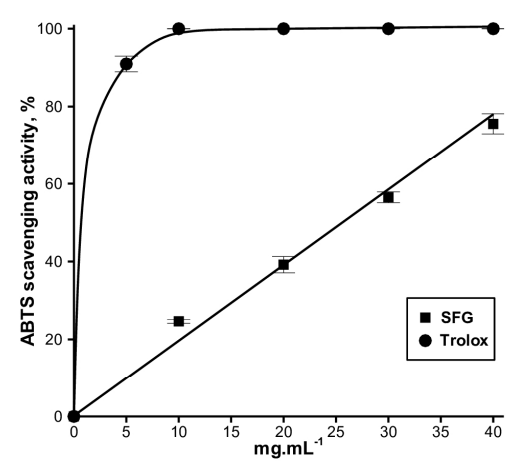

(d)

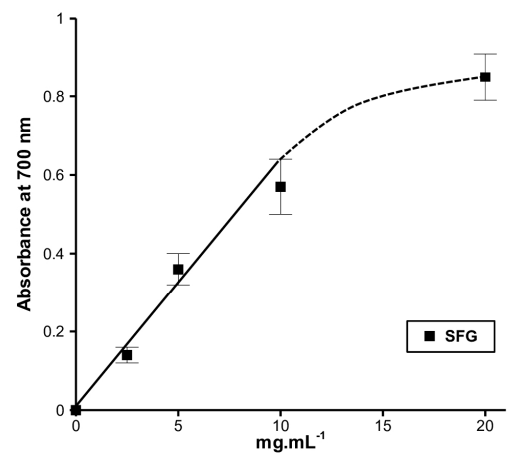

(e)

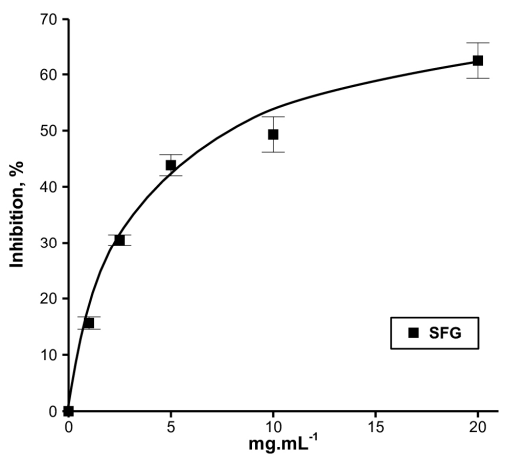

Figure 3. Antioxidant activities of soluble flaxseed gum (SFG): (a) 2,2-diphenyl-1-picrylhydrazyl (DPPH) scavenging activity,; (b) 2,2'-azino-bis(3-ethylbenzothiazoline-6-sulphonic acid (ABTS) scavenging activity; (c) total antioxidant activity; (d) reducing power capacity; (e) $\beta$-carotene bleaching activity. Trolox and BHA were used as standard molecules. Continuous lines are given to guide the eye.

The reduction of phosphomolybdate was followed by the measurement of total antioxidant capacity (TAC). A green complex of phosphate/Mo (V) is formed at acidic $\mathrm{pH}$, which has a maximal absorbance at $695 \mathrm{~nm}$. The TAC of SFG extracted from hulls was determined as described previously, and was expressed as ascorbic acid equivalent (AAE) $/ \mathrm{mL}$ (Figure $3 \mathrm{c}$ ). The obtained results indicate that the TAC was proportional to the concentration of SFG, with linearity up to $10 \mathrm{mg} \cdot \mathrm{mL}^{-1}$. At this concentration, $10 \mathrm{mg}$ of SFG was equivalent to $461 \mathrm{mg}$ ascorbic acid. Beyond this concentration, TAC continues to increase with lower slope, indicating saturation of the medium. Although the lower antioxidant activity compared to that of ascorbic acid, the obtained results indicate that SFG represents an interesting natural antioxidant molecule. 
Moreover, the reducing capacity of SFG to convert $\mathrm{Fe}^{3+}$ to $\mathrm{Fe}^{2+}$ was followed by measuring the absorbance (A) at $700 \mathrm{~nm}$, corresponding to the formation of Perl's Prussian blue at $700 \mathrm{~nm}$ (Figure 3d). The obtained results indicate that SFG reducing power was proportional to the concentration of SFG. The absorbance showed linearity until $10 \mathrm{mg} \cdot \mathrm{mL}^{-1}$, similar to TAC, and then the slope decreased beyond this concentration. Although the results were promising, SFG reducing capacity was lower than that reported in the literature for other polysaccharides, such as those extracted from almond juice processing by-product $\left(\mathrm{A}_{700 \mathrm{~nm}}=1.5\right.$ at $\left.5 \mathrm{mg} \cdot \mathrm{mL}^{-1}\right)$ [41], pistachio juice processing by-product $\left(\mathrm{A}_{700 \mathrm{~nm}}=1.74\right.$ at $\left.5 \mathrm{mg} \cdot \mathrm{mL}^{-1}\right)$ [41], mushroom $\left(\mathrm{A}_{700 \mathrm{~nm}}=3.4\right.$ at $\left.20 \mathrm{mg} \cdot \mathrm{mL}^{-1}\right)$ [46], and from almond $\operatorname{gum}\left(\mathrm{A}_{700 \mathrm{~nm}}=1.36\right.$ at $\left.12 \mathrm{mg} \cdot \mathrm{mL}^{-1}\right)$ [27].

Finally, the $\beta$-carotene bleaching test simulates the oxidation of lipids' membrane; thus, it is considered a good model for membrane-based lipid peroxidation. The oxidation of linoleic acid during this assay generates peroxyl free radicals, which are able to oxidize the unsaturated $\beta$-carotene. The presence of an antioxidant molecule in the medium will minimize this oxidation. Therefore, the antioxidant activity of SFG could be measured by following the degradation rate of $\beta$-carotene. The obtained results (Figure 3d) show that the inhibition increased proportionally to the concentration of SFG up to $20 \mathrm{mg} \cdot \mathrm{mL}^{-1}$. The maximum measured inhibition corresponding to this concentration was $62.4 \% \pm 3.1 \%$, thus showing the efficiency of SFG as a natural antioxidant.

\section{Conclusions}

In conclusion, the in vitro antioxidant capacity of soluble flaxseed gum extracted from hulls was demonstrated. Results showed great antioxidant activities through numerous tests, and were compared to commercial standard molecules. SFG presented similar functional groups when compared to gum arabic, which suggests its polysaccharidic structure. These results show the promising potential of flaxseed hulls as a co-product to be fully exploited and extract food additives that could replace other commercial gums, such as gum arabic. However, further studies should be conducted to explain the mechanisms behind these activities.

Acknowledgments: This work was funded by the Ministry of Higher Education and Scientific Research of Tunisia.

Author Contributions: Fatma Bouaziz and Mohamed Koubaa conceived, designed and performed the experiments; Mohamed Koubaa, Francisco J. Barba, Shahin Roohinejad and Semia Ellouz Chaabouni supervised the study, wrote and reviewed the manuscript. All authors have read and approved the final manuscript.

Conflicts of Interest: The authors declare no conflict of interest.

\section{References}

1. Cunnane, S.C.; Thompson, L.U. Flaxseed in Human Nutrition; AOCS Press: Champaign, IL, USA, 1995.

2. Hall, C., III; Tulbek, M.C.; Xu, Y. Advances in Food and Nutrition Research; Taylor, S., Ed.; Elsevier Inc.: San Diego, CA, USA, 2006; Volume 51, pp. 1-97.

3. Obranović, M.; Škevin, D.; Kraljić, K.; Pospišil, M.; Blekić, M.; Putnik, P. Influence of climate, variety and production process on tocopherols, plastochromanol-8 and pigments in flaxseed oil. Food Technol. Biotechnol. 2015, 53, 496-504. [CrossRef]

4. Thompson, L.U.; Cunnane, S.C. Flaxseed in Human Nutrition, 2nd ed.; AOCS Press: Champaign, IL, USA, 2003.

5. Qian, K.Y. Structure-Function Relationship of Flaxseed Gum from Flaxseed Hulls. Ph.D. Thesis, University of Guelph, Guelph, ON, Canada, 2014.

6. Cui, W.; Mazza, G.; Oomah, B.D.; Biliaderis, C.G. Optimization of an aqueous extraction process for flaxseed gum by response surface methodology. LWT Food Sci. Technol. 1994, 27, 363-369. [CrossRef]

7. Mazza, G.; Biliaderis, C.G. Functional properties of flax seed mucilage. J. Food Sci. 1989, 54, $1302-1305$. [CrossRef]

8. Bassett, C.M.C.; Rodriguez-Leyva, D.; Pierce, G.N. Experimental and clinical research findings on the cardiovascular benefits of consuming flaxseed. Appl. Physiol. Nutr. Metab. 2009, 34, 965-974. [CrossRef] [PubMed] 
9. Bloedon, L.T.; Szapary, P.O. Flaxseed and cardiovascular risk. Nutr. Rev. 2004, 62, 18-27. [CrossRef] [PubMed]

10. Menteş, Ö.; Bakkalbaşşi, E.; Ercan, R. Effect of the use of ground flaxseed on quality and chemical composition of bread. Food Sci. Technol. Int. 2008, 14, 299-306. [CrossRef]

11. Rendón-Villalobos, J.R.; Bello-Pérez, L.A.; Agama-Acevedo, E.; Islas-Hernández, J.J.; Osorio-Díaz, P.; Tovar, J. Composition and characteristics of oil extracted from flaxseed-added corn tortilla. Food Chem. 2009, 117, 83-87. [CrossRef]

12. Warrand, J.; Michaud, P.; Picton, L.; Muller, G.; Courtois, B.; Ralainirina, R.; Courtois, J. Flax (Linum usitatissimum) seed cake: A potential source of high molecular weight arabinoxylans? J. Agric. Food Chem. 2005, 53, 1449-1452. [CrossRef] [PubMed]

13. Thakur, G.; Mitra, A.; Pal, K.; Rousseau, D. Effect of flaxseed gum on reduction of blood glucose and cholesterol in type 2 diabetic patients. Int. J. Food Sci. Nutr. 2009, 60, 126-136. [CrossRef] [PubMed]

14. Fodje, A.M.L.; Chang, P.R.; Leterme, P. In vitro bile acid binding and short-chain fatty acid profile of flax fiber and ethanol co-products. J. Med. Food 2009, 12, 1065-1073. [CrossRef] [PubMed]

15. Cui, S.W. Flaxseed gum. In Polysaccharide Gums from Agricultural Products: Processing, Structures and Functionality; Cui, S.W., Ed.; Technomic Pub. Co.: Lancaster, UK, 2000; pp. 59-101.

16. Oomah, B.D.; Sitter, L. Characteristics of flaxseed hull oil. Food Chem. 2009, 114, 623-628. [CrossRef]

17. Loginov, M.; Boussetta, N.; Lebovka, N.; Vorobiev, E. Separation of polyphenols and proteins from flaxseed hull extracts by coagulation and ultrafiltration. J. Membr. Sci. 2013, 442, 177-186. [CrossRef]

18. Boussetta, N.; Soichi, E.; Lanoisellé, J.-L.; Vorobiev, E. Valorization of oilseed residues: Extraction of polyphenols from flaxseed hulls by pulsed electric fields. Ind. Crops Prod. 2014, 52, 347-353. [CrossRef]

19. Kaushik, P.; Dowling, K.; McKnight, S.; Barrow, C.; Adhikari, B. Microencapsulation of flaxseed oil in flaxseed protein and flaxseed gum complex coacervates. Food Res. Int. 2016, 86, 1-8. [CrossRef]

20. Xu, D.; Aihemaiti, Z.; Cao, Y.; Teng, C.; Li, X. Physicochemical stability, microrheological properties and microstructure of lutein emulsions stabilized by multilayer membranes consisting of whey protein isolate, flaxseed gum and chitosan. Food Chem. 2016, 202, 156-164. [CrossRef] [PubMed]

21. Pan, L.; Feng, M.; Sun, J.; Chen, X.; Xu, X.; Zhou, G. Thermal gelling properties and mechanism of porcine myofibrillar protein containing flaxseed gum at various $\mathrm{pH}$ values. J. Food 2016, 14, 547-554. [CrossRef]

22. Liu, J.; Shen, J.; Shim, Y.Y.; Reaney, M.J.T. Carboxymethyl derivatives of flaxseed (Linum usitatissimum L.) gum: Characterisation and solution rheology. Int. J. Food Sci. Technol. 2016, 51, 530-541. [CrossRef]

23. Zhang, Y.; Li, D.; Wang, L.J.; Adhikari, B. Rheological and microstructural characteristics of thermally produced flaxseed gum-whey protein isolate mixed solutions and gels. Dry. Technol. 2013, 31, 1635-1642. [CrossRef]

24. Wang, L.; Huang, X.; Bi, C.; Li, D. Physical properties and rheological properties of flax gum-agar mixed gel system. Nongye Jixie Xuebao Trans. Chin. Soc. Agric. Mach. 2013, 44, 193-197, 247. (In Chinese)

25. Koubaa, M.; Driss, D.; Bouaziz, F.; Ellouz Ghorbel, R.; Ellouz Chaabouni, S. Antioxidant and antimicrobial activities of solvent extract obtained from rocket (Eruca sativa L.) flowers. Free Radic. Antioxid. 2015, 5, $29-34$. [CrossRef]

26. Koubaa, M.; Ktata, A.; Barba, F.J.; Grimi, N.; Mhemdi, H.; Bouaziz, F.; Driss, D.; Chaabouni, S.E. Water-soluble polysaccharides from Opuntia stricta Haw. fruit peels: Recovery, identification and evaluation of their antioxidant activities. Int. Agrophysics 2015, 29, 299-306. [CrossRef]

27. Bouaziz, F.; Koubaa, M.; Helbert, C.B.; Kallel, F.; Driss, D.; Kacem, I.; Ghorbel, R.; Chaabouni, S.E. Purification, structural data and biological properties of polysaccharide from Prunus amygdalus gum. Int. J. Food Sci. Technol. 2015, 50, 578-584. [CrossRef]

28. Kallel, F.; Driss, D.; Bouaziz, F.; Belghith, L.; Zouari-Ellouzi, S.; Chaari, F.; Haddar, A.; Chaabouni, S.E.; Ghorbel, R. Polysaccharide from garlic straw: Extraction, structural data, biological properties and application to beef meat preservation. RSC Adv. 2014, 5, 6728-6741. [CrossRef]

29. Sila, A.; Bayar, N.; Ghazala, I.; Bougatef, A.; Ellouz-Ghorbel, R.; Ellouz-Chaabouni, S. Water-soluble polysaccharides from agro-industrial by-products: Functional and biological properties. Int. J. Biol. Macromol. 2014, 69, 236-243. [CrossRef] [PubMed]

30. Koubaa, M.; Mhemdi, H.; Vorobiev, E. Influence of canola seed dehulling on the oil recovery by cold pressing and supercritical $\mathrm{CO}_{2}$ extraction. J. Food Eng. 2016, 182, 18-25. [CrossRef] 
31. AFNOR. Recueil de Normes Françaises des Produits Dérivés des Fruits et Légumes Jus de Fruits; Association Française de Normalisation: Paris, France, 1982.

32. AFNOR. Determination of Nitrogen for the Calculation of Crude Protein Content; Association Française de Normalisation: Paris, France, 1977.

33. Dubois, M.; Gilles, K.A.; Hamilton, J.K.; Rebers, P.A.; Smith, F. Colorimetric method for determination of sugars and related substances. Anal. Chem. 1956, 28, 350-356. [CrossRef]

34. Jorhem, L. Determination of metals in foods by atomic absorption spectrometry after dry ashing: NMKL Collaborative Study. J. AOAC Int. 2000, 83, 1204-1211.

35. Re, R.; Pellegrini, N.; Proteggente, A.; Pannala, A.; Yang, M.; Rice-Evans, C. Antioxidant activity applying an improved ABTS radical cation decolorization assay. Free Radic. Biol. Med. 1999, 26, 1231-1237. [CrossRef]

36. Yildirim, A.; Mavi, A.; Kara, A.A. Determination of antioxidant and antimicrobial activities of Rumex crispus L. extracts. J. Agric. Food Chem. 2001, 49, 4083-4089. [CrossRef] [PubMed]

37. Wiesenborn, D.; Tostenson, K.; Kangas, N. Continuous abrasive method for mechanically fractionating flaxseed. J. Am. Oil Chem. Soc. 2003, 80, 295-300. [CrossRef]

38. Edel, A.L.; Aliani, M.; Pierce, G.N. Stability of bioactives in flaxseed and flaxseed-fortified foods. Food Res. Int. 2015, 77, 140-155. [CrossRef]

39. Wu, C.S. Renewable resource-based composites of recycled natural fibers and maleated polylactide bioplastic: Characterization and biodegradability. Polym. Degrad. Stable 2009, 94, 1076-1084. [CrossRef]

40. Yao, F.; Chen, W.; Wang, H.; Liu, H.; Yao, K.; Sun, P.; Lin, H. A study on cytocompatible poly(chitosan-g-L-lactic acid). Polymer 2003, 44, 6435-6441. [CrossRef]

41. Sila, A.; Sayari, N.; Balti, R.; Martinez-Alvarez, O.; Nedjar-Arroume, N.; Moncef, N.; Bougatef, A. Biochemical and antioxidant properties of peptidic fraction of carotenoproteins generated from shrimp by-products by enzymatic hydrolysis. Food Chem. 2014, 148, 445-452. [CrossRef] [PubMed]

42. Zhao, G.; Kan, J.; Li, Z.; Chen, Z. Structural features and immunological activity of a polysaccharide from Dioscorea opposita Thunb roots. Carbohydr. Polym. 2005, 61, 125-131. [CrossRef]

43. Hua, D.; Zhang, D.; Huang, B.; Yi, P.; Yan, C. Structural characterization and DPPH.radical scavenging activity of a polysaccharide from Guara fruits. Carbohydr. Polym. 2014, 103, 143-147. [CrossRef] [PubMed]

44. Bouaziz, F.; Koubaa, M.; Neifar, M.; Zouari-Ellouzi, S.; Besbes, S.; Chaari, F.; Kamoun, A.; Chaabouni, M.; Chaabouni, S.E.; Ghorbel, R.E. Feasibility of using almond gum as coating agent to improve the quality of fried potato chips: Evaluation of sensorial properties. LWT Food Sci. Technol. 2016, 65, 800-807. [CrossRef]

45. Bouaziz, F.; Koubaa, M.; Kallel, F.; Chaari, F.; Driss, D.; Ghorbel, R.E.; Chaabouni, S.E. Efficiency of almond gum as a low-cost adsorbent for methylene blue dye removal from aqueous solutions. Ind. Crops Prod. 2015, 74, 903-911. [CrossRef]

46. Kozarski, M.; Klaus, A.; Nikšić, M.; Vrvić, M.M.; Todorović, N.; Jakovljević, D.; van Griensven, L.J.L.D. Antioxidative activities and chemical characterization of polysaccharide extracts from the widely used mushrooms Ganoderma applanatum, Ganoderma lucidum, Lentinus edodes and Trametes Versicolor. J. Food Compos. Anal. 2012, 26, 144-153. [CrossRef]

(c) 2016 by the authors; licensee MDPI, Basel, Switzerland. This article is an open access article distributed under the terms and conditions of the Creative Commons Attribution (CC-BY) license (http://creativecommons.org/licenses/by/4.0/). 